Article

\title{
Technical, Environmental, and Qualitative Assessment of the Oak Waste Processing and Its Usage for Energy Conversion
}

\author{
Algirdas Jasinskas ${ }^{1, *}$, Ramūnas Mieldažys ${ }^{1}$ (D), Eglè Jotautienè ${ }^{1}$, Rolandas Domeika ${ }^{1}$ (D), \\ Edvardas Vaiciukevičius ${ }^{1}$ and Marek Marks ${ }^{2}$ \\ 1 Institute of Agricultural Engineering and Safety, Vytautas Magnus University, 48005 Kaunas District, \\ Lithuania; ramunas.mieldazys@vdu.lt (R.M.); egle.jotautiene@vdu.lt (E.J.); rolandas.domeika@vdu.lt (R.D.); \\ edvardas.vaiciukevicius@vdu.lt (E.V.) \\ 2 Department of Agroecosystems, University of Warmia and Mazury in Olsztyn, 10-726 Olsztyn, Poland; \\ marek.marks@uwm.edu.pl \\ * Correspondence: algirdas.jasinskas@vdu.lt; Tel.: +370-612-04002
}

Received: 31 August 2020; Accepted: 29 September 2020; Published: 1 October 2020

check for updates

\begin{abstract}
The article analyses and evaluates the possibilities of using oak bark, oak leaves, and their mixtures for biofuel. The preparation of this waste for the burning process (milling, granulation) has been investigated and the results have been presented together with the analysis of the prepared granules' properties-humidity, density, strength, elemental composition, ash content, caloric value, and others. The moisture content of the oak waste granules ranged from $8.1 \%$ to $12.5 \%$, and the granules' density ranged from 975.8 to $1122.2 \mathrm{~kg} \mathrm{~m}^{-3} \mathrm{DM}$ (dry matter). The amount of oak ash found was very high (from $10.4 \%$ to $14.7 \%$ ) - about 10 times higher than that of wood waste granules. The calorific value determined after burning the oak bark and leaves pellets was sufficiently high, ranging from 17.3 to $17.7 \mathrm{MJ} \mathrm{kg}^{-1}$. This thermal value of oak waste granules was close to the calorific value of the herbaceous plant species and some types of wood waste. The environmental impact of burning the granules of oak waste was also assessed. The harmful emissions of carbon monoxide and dioxide, nitrogen oxides, and unburnt hydrocarbons into the environment were found to be below the permissible limits for the incineration of oak waste granules. The highest $\mathrm{CO}$ gas concentration, determined when burning the oak leaves, was $1187.70 \mathrm{mg} \mathrm{m}^{-3}$, and the lowest $\mathrm{NO}_{\mathrm{x}}$ concentration, determined when burning the oak bark and leaf mixture granules, was $341.2 \mathrm{mg} \mathrm{m}^{-3}$. The coefficient of energy efficiency $R$ of the granulated oak leaves biofuel, when the oak waste biomass moisture content was reduced by $10 \%$, reached 3.64. It was very similar to the results of previous studies of various types of granulated straw biofuel (3.5-3.7). The research results presented show that, given that the main parameters of oak waste meet the basic requirements of solid biofuel, oak bark, leaves, and their mixture can be recommended to be used as solid biofuels.
\end{abstract}

Keywords: oak waste; biofuel; granules; properties; burning; harmful emissions; energy efficiency

\section{Introduction}

In Lithuania and other countries, wood resources are limited and can be used in other processes; much attention is paid to research on granule production from various non-stem wood biomass and its residues. The results of the studies of Filbakk et al. [1] showed that the biofuel granules with a higher amount of bark have a higher bulk density and lower mill content. However, these granules have a higher content of ash as well.

Verma et al. [2] states that the combustion efficiency and emission levels of different types of granules are different. The article deals with granules of wood, peat, apple, reed canary grass, sunflower, 
and the waste of citrus pectin. In the production of solid wood biofuel, the chopped and milled plant biomass is compressed to high density, resulting in a relatively high burning efficiency. The cylindrical shape of granular products facilitates long-distance transportation, takes up less storage space, and facilitates the control of boiler burners [3].

The production of granules from dry raw material with a low moisture content results in a high density and uniformity, making granules more suitable for transportation and storage than products made from excessively moist biomass. Replacing fossil fuels with biofuel granules is relatively easy in existing power plants and heat energy-producing companies [4].

The variety of chemical and physical-mechanical properties of the granules of wood biomass influences the quality of the fuel. First of all, Johansson et al. [5] demonstrated that density, moisture, ash, fine particles, and lower calorific value have a significant impact on the efficiency of fuel energy systems and emissions. The work of Stahl and Wikström [6] suggests that the efficiency of the combustion process decreases if the use of fuel results in a high ash content. The research of Samuelsson et al. [7] drew attention to an important fact that the moisture content of biomass feedstock has a significant effect on the density and the calorific value of the final product. It has been determined that the average diameter and average length of the granules should also be taken into account, as there are standardized granule delivery systems and technologies on the EU market [8]. The research of Dias et al. [9] shows that the utilization of granules of a bigger diameter reduces the efficiency of the boiler, while granules with a smaller mechanical durability have finer particles and a lower combustion efficiency.

The work performed by Stahl and Wikström [6] defines the influence of granules' bulk density on the boiler efficiency. Changes in the bulk density affect the behaviour of the combustion process and increase the heat loss in boilers without automatic control. Mechanical durability, fine material content, and granule density are the factors important for transportation. Filbakk et al. [1] claimed that high concentrations of fine particles can cause problems with the quality of granules' burning and may lead to reduced efficiency $[10,11]$. Thus, it can be stated that several parameters are necessary for a proper burning process.

Various types of wood waste can be used for burning. For this purpose, it is possible to use not only wood waste from industrial wood processing and the furniture manufacturing industry, but also small branches, bark, and leaves. Research on various types of energy plant forests and the preparation and use of agricultural residues for domestic energy supply in Lithuania was presented [12,13]. Oak wood is one of the highest quality woods growing in Lithuania. It is therefore appropriate to investigate the recycling and use of oak wood waste for incineration.

Recently, the importance and relevance of the global ecological problem caused by harmful gas emissions from the combustion of different fuels have been increasing. It is recommended to use environmentally friendly vegetative origin biofuel. In addition to the fact that it contains almost no harmful substances, the carbon dioxide released in the process of the photosynthesis of plants is converted into oxygen during the combustion process [14].

Individual countries use different local or imported fuel for their energy needs; therefore, the emissions of pollutants into the environment differ. European countries with large populations, such as Poland and Germany, pollute the environment mainly with $\mathrm{CO}_{2}, \mathrm{NO}_{\mathrm{x}}$, and $\mathrm{SO}_{2}$. The highest intensity of $\mathrm{CO}_{2}$ emissions was found in Poland, Germany, Estonia, and Denmark. These countries have their own energy supply from the local fossil fuel, but at least emit pollutants into the environment of the Scandinavian countries, where hydro, bio, and nuclear energy resources are used [15].

The limits of the emissions from combustion equipment are regulated by the Ministry of Environment of the Republic of Lithuania, which has approved the emission rates from fuel burning equipment [16]. These rates regulate the maximum allowed emission values from the burning of biofuels, including straw and herbaceous plants. There is estimated new and existing biofuel burning equipment with a thermal output from 0.12 to $1.0 \mathrm{MW}$, the emission limit value (in the standard $\mathrm{O}_{2}$ is $6 \%$ for the concentration of bulk percentage) for $\mathrm{SO}_{2}$ is $2000 \mathrm{mg} \mathrm{Nm}^{-3}$, for $\mathrm{NO}_{\mathrm{x}}$ is $750 \mathrm{mg} \mathrm{Nm}^{-3}$, $\mathrm{CO}$ is not rated, and for solid particles it is $800 \mathrm{mg} \mathrm{Nm}^{-3}$. 
Burning one tonne of grass or straw furnace plant results in 30-40 $\mathrm{kg}$ of ash and 5 to $8 \mathrm{~kg}$ of dust remaining in the filters. Ash contains approximately $0.09 \%$ nitrogen, $1.0 \%$ phosphorus, and $11 \%$ potassium, as well as small amounts of heavy metals such as copper, zinc, tin, nickel, cadmium, chromium, and others. Phosphorus and potassium in the ash allows us to use it as a fertilizer [17].

Biomass is a highly efficient and secure source of thermal energy, especially in a long-term low-carbon economy. Biomass for heating can be $85 \%$ more efficient than electricity generation or biofuel transport, which is characterized by higher energy loss in conversion processes. Nevertheless, the low bulk density of biomass encourages operators to carry out compaction processes (granulation, pelleting, and briquetting) before using energy to take advantage of the homogeneous and easily automated solid biofuels that additionally have higher energy densities. The global consumption of biofuel granules is expected to increase to $68-80$ million tonnes by $2020[18,19]$.

The biomass density of wood and other plants is low due to their porous structure. It ranges from 40 to $150 \mathrm{~kg} \mathrm{~m}^{-3}$ for grass-type biomass [20,21] and from 320 to $720 \mathrm{~kg} \mathrm{~m}^{-3}$ for most types of dried hard and soft trees [22]. In practice, the density of chopped biomass is several times lower and reaches $150-200 \mathrm{~kg} \mathrm{~m}^{-3}$ [23], being generally lower than that of the firewood.

Produced biomass granules can have densities ranging from 1000 to $1400 \mathrm{~kg} \mathrm{~m}^{-3}$ [24], and a bulk density of approximately $700 \mathrm{~kg} \mathrm{~m}^{-3}$ [25]. This process improves the transportation and storage of granules, and provides better biomass handling as well as lower dust generation [26,27].

Wood biomass and wood waste are considered to be the dominant raw materials for granule production, except for agricultural waste. Agricultural and forestry waste was the main fuel source for potential bioenergy projects in some developing countries [28]. Magelli et al. investigated the consumption and the emissions of wood granules in Columbia [29]. Rhén et al. analysed the effect of the composition of wood granules on their burning characteristics [30]. It was determined that bark granules had a more than $50 \%$ longer combustion time than wood stem granules.

$\mathrm{Li}$ and other researchers have studied the granulation of torrefied sawdust from a fluidized bed reactor to quantify the energy consumption and to assess the properties of the granules produced [31]. It was determined that a higher energy consumption was needed for the production of torrefied sawdust compared to the untreated, raw sawdust at the same compression temperature. Lam and other researchers have investigated the energy consumption and quality of granules produced by a steam-exploded Douglas Fir [32]. The research results showed that the steam-treated wood requires more energy to produce granules, and the resistance of granules to compression was higher than that of untreated wood.

Stem wood, bark, and branches have different structures and chemical compositions, such as lignin, cellulose, hemicellulose, pectin, and extracts. In addition, the processes of hydrolysis, autoxidation, and microbial degradation have a significant impact on its properties during raw material storage [33].

The aim of this work was to investigate the technological-technical means of preparation of oak waste for compressed biofuels; to evaluate its physical-mechanical, chemical, and thermal properties; to evaluate the quality indicators of granule production and its use for incineration; and to assess the environmental impact of the combustion of oak waste granules in a low-capacity boiler.

The novelty of the article presented comes from the fact that the possibilities for the processing and utilization of oak waste for energy conversion, granulated biofuel production, burning, and heat energy production were investigated. Many researchers analyse and compare only some individual properties of biofuels, whereas in this work the authors comprehensively evaluate many investigated properties, such as the moisture content, density, and mechanical strength of pellets and their variations, as well as emissions of harmful gases, etc., which are the main characteristics defining the quality of the pellets produced. 


\section{Materials and Methods}

\subsection{Oak Waste Chopping and Milling Quality}

Research on the preparation and use of oak waste for energy purposes was carried out at the laboratories of Vytautas Magnus University Agriculture Academy in Lithuania. The quality of the raw material prepared for the biofuel production and the processed granules must meet the requirements of the combustion chambers, as well as the requirements for the transportation and storage of ready-made products.

A drum shredder of herbaceous plant harvester Maral 125 (Germany) was used for shredding the oak bark and its leaves in the experimental research of oak waste. In addition, in order to use the ready-made raw material for granules' production, it is necessary to chop it into a milling consistency (1-2 mm particles). A laboratory mill, the Retsch SM 200 (Germany), was used for this purpose [34].

The quality of the chopped mass milling was determined by the methodology of the European Union countries [35]. Each sample of $3 \mathrm{~kg}$ was sieved for $2 \mathrm{~min}$ with a sieve shaker Haver EML 450 Digital plus with a sieve set (Germany). The fractional composition of milled oak waste was determined using a sieve set of $200 \mathrm{~mm}$ sieves with round holes (starting from the top sieve) that were 2.0, 1.0, 0.63, 0.5, and $0.25 \mathrm{~mm}$ in diameter. The milled mass remaining on each sieve was weighted and a sample part of every fraction was calculated (in percentage). These tests were repeated 3 times.

The bulk density of the milled raw material was determined using an empty $6 \mathrm{dm}^{3}$ cylinder. The oak waste mill was added to the cylinder to the top edge and was weighted. Knowing the mill mass and the volume of the cylinder allowed us to calculate the bulk density of the mill. The moisture content of the mill was determined in the chemical laboratory according to the standard methodology $[34,36]$.

\subsection{Production and Determination of Granules' Biometrical and Physical-Mechanical Properties}

The chopped and milled raw material was granulated with a low-power $(7.5 \mathrm{~kW})$ biomass granulator ZLSP200B (Poland) with a horizontal matrix (with a capacity of 100-120 $\mathrm{kg} \mathrm{h}^{-1}$ ). The diameter of the produced granules was $6 \mathrm{~mm}$. It was granulated in a conventional manner: the grounded mill was well mixed and moistened (if it was too dry for granulating), dosed into a pressure chamber where the mass was pressed through matrix holes $6 \mathrm{~mm}$ in diameter, and finally the granules were produced.

The dimensions, moisture content, volume, density, and strength of the granules were determined after cooling the granules. The parameters of the granules were assessed by measuring their height and diameter. A digital Vernier caliper LIMIT $150 \mathrm{~mm}$ (PRC) with a measuring accuracy of $0.01 \mathrm{~mm}$ was used for this purpose. KERN ABJ (Germany) scales with an accuracy of $0.001 \mathrm{~g}$ were used to determine the mass of the granules. The mass of the granules was determined for each sample type by using 10 granules with an average mean error.

The moisture content of the investigated granules was determined analogously to the flour, according to the standard methodology, by drying the pellets in a laboratory dryer $[36,37]$.

The compressive strength of the granules was determined using an Instron 5965 universal testing machine (ITW, USA) with a capacity of $5 \mathrm{kN}$. The table model 5965 load frames meet the requirements of the EN61236-1 (2006). The received parameters were saved in the Instron Bluehill test control software (version 3.11.1209). Static load velocities of $20 \mathrm{~mm} \mathrm{~min}^{-1}$ and a movement limit were selected. Experiments with the samples of granules were carried out in a horizontal plane. Each test was completed 5 times per sample. The experiment results were recorded every 0.1 seconds until the granule was disintegrated. The measurement error was $0.02 \%$. Statistical mathematical methods were used for processing the data obtained. The average values and their confidence intervals (CI) were calculated with the probability level of 0.95 . 


\subsection{Elemental Composition, Ash Content and Calorific Value of Oak Waste Granules}

The elemental composition and the ash content of the granules were determined in the laboratories of the Lithuanian Energy Institute (LEI) according to the current Lithuanian and EU standard methodology using the following devices: Flash 2000 (US), according to the standard LST EN 14774-1: 2010; humidity tester no. 8B / 1, according to the standard LST EN 14775: 2010; ash test unit no. 8B / 5 . The calorific value $\left(\mathrm{kJ} \mathrm{kg}^{-1}\right)$ of oak waste granules was determined using a calorimeter C 2000 (IKA, Germany) according to the standard methodology (BS EN 14918: 2009).

\subsection{Evaluation of Harmful Gas Emissions from Burning Oak Waste Pellets}

The fuel combustion and emissions depend on the type and quality of the fuel and the formation of solid biofuel in boilers. These fuel indicators are important for new fuel supply as well as for combustion equipment. In order to determine the influence of these parameters on the formation of pollutants, research was carried out in a low-power $(5 \mathrm{~kW})$ solid-fuel boiler adapted to use a large fraction of fuel: wood, sawdust briquettes, and pellets. Investigations were carried out in LEI. The pollutants were measured in the exhaust gas analysers DATATEST 400 CEM, VE7 (Germany) during the combustion process. The content of total carbon, hydrogen, nitrogen, sulphur and oxygen was measured according to the requirements of the standard EN 15104: 2010.

While burning the oak waste granules, the smoke temperature was recorded and harmful emissions of carbon dioxide $\left(\mathrm{CO}_{2}\right)$, carbon monoxide $(\mathrm{CO})$, sulphur dioxide $\left(\mathrm{SO}_{2}\right)$, nitrogen oxides $\left(\mathrm{NO}_{\mathrm{x}}\right)$, and unburnt hydrocarbons $\left(\mathrm{C}_{\mathrm{x}} \mathrm{H}_{\mathrm{y}}\right)$ were determined. After assessing the release of harmful pollutants into the environment, they were compared with the combustion of various types of granulated biofuel produced from the oak waste: bark, leaves, and their mixtures (1:1). Each sample was burned for 8-10 min.

The content of total carbon, hydrogen, nitrogen, sulphur, and oxygen was measured according to the requirements of the standard EN 15104:2010.

\subsection{Energy Evaluation of Granulated Oak Waste Biofuel Technology}

Technological operations were justified and proposed, and the technique was selected for the evaluation of biofuel preparation from granulated oak waste (leaves, bark, and their mixtures). The following most important technological operations for the granule preparation and burning were selected and the direct energy consumption of the granulated biofuel from oak leaves was calculated:

- Total energy consumption for the collection of leaves into piles.

- Loading of oak leaves into vehicle trailers and their transportation to storage facilities.

- Milling and drying of biomass in a dryer-dispergator, reducing the moisture content by 10 percentage points (from $25 \%$ to $15 \%$ ).

- Biomass granule production in a low-power $(7.5 \mathrm{~kW})$ granulator.

- Energy consumption of granule transportation and burning implements.

The oak waste (leaves) energy indicators were determined according to the standard requirements [13,34].

An analysis of the variance of the research results was performed for three replications using the F-test and the LSD (95\% probability level) to assess the reliability and the statistical significance of the results.

\section{Results and Discussion}

\subsection{Determination of Mill Physical-Mechanical Properties}

In order to ensure the convenient and efficient use of fuel for combustion when processing plant biomass and preparing it for combustion, it is important to increase the density and the energy value 
of the raw material as much as possible and to ensure automated fuel supply to the furnace. This is achieved by compressing the biomass into granules. The volume of pressed material could be reduced up to 10 times. Leaves and bark of trees growing in forests and parks can also be used as a raw material for this fuel.

Before preparing the pellets, the plant biomass was chopped and milled and its properties were investigated. The physical-mechanical properties of milled oak waste-moisture content and density -were determined. These properties are important for designing and selecting the appropriate transportation and storage facilities. The moisture content and the density of the milled oak waste are presented in Table 1.

Table 1. The moisture content and density of the oak waste mill.

\begin{tabular}{ccc}
\hline Oak Waste Mill & Moisture Content, $\%$ & Mass Density, $\mathbf{~ k g ~ m}^{-3}$ \\
\hline Bark & $6.1 \pm 0.4$ & $278.3 \pm 4.5(261.3 \mathrm{DM})$ \\
Leaves & $9.6 \pm 0.2$ & $214.7 \pm 5.2(194.1 \mathrm{DM})$ \\
Bark and leaves mixture (1:1) & $7.9 \pm 0.3$ & $246.5 \pm 4.8(227.0 \mathrm{DM})$ \\
\hline
\end{tabular}

As can be seen from Table 1, the highest density is from the oak bark mill, at $261.3 \mathrm{~kg} \mathrm{~m}^{-3} \mathrm{DM}$ (dry matter), and the density of oak leaves is the lowest, with only $194.1 \mathrm{~kg} \mathrm{~m}^{-3} \mathrm{DM}-1.3$ times lower than that of the oak bark mill.

The fractional composition of the oak waste mill (in \%) is presented in Table 2. After the evaluation of the fractional composition of the milled oak waste, we can see that the biggest fraction of bark mill was selected on the sieve with holes $0.25 \mathrm{~mm}$ in diameter $(46.2 \pm 6.6 \%)$. An excessive amount of dust $(24.3 \pm 2.3 \%)$ was found as well.

Table 2. Fractional composition of the oak waste mill.

\begin{tabular}{ccccccc}
\hline $\begin{array}{c}\text { Fractional Composition } \begin{array}{c}\text { of } \\
\text { of }\end{array} \\
\text { the Oak Waste Mill }\end{array}$ & $\mathbf{0 - 0 . 2 5}$ & $\mathbf{0 . 2 5 - 0 . 5}$ & $\mathbf{0 . 5}-\mathbf{0 . 6 3}$ & $\mathbf{0 . 6 3 - 1 . 0}$ & $\mathbf{1 . 0 - 2 . 0}$ & $\mathbf{> 2 . 0}$ \\
\cline { 2 - 7 } & $24.3 \pm 2.3$ & $46.2 \pm 6.6$ & $7.9 \pm 2.1$ & $19.2 \pm 6.2$ & $2.4 \pm 1.4$ & 0 \\
Bark & $22.0 \pm 2.5$ & $30.9 \pm 2.9$ & $11.7 \pm 2.2$ & $28.1 \pm 3.2$ & $7.3 \pm 2.1$ & 0 \\
$\begin{array}{c}\text { Leaves } \\
\text { Bark and leaves mixture } \\
(1: 1)\end{array}$ & $23.8 \pm 2.1$ & $37.4 \pm 5.4$ & $10.3 \pm 4.4$ & $22.9 \pm 2.9$ & $5.6 \pm 2.2$ & 0 \\
\hline
\end{tabular}

Analysis of the information presented in Table 2 allows us to conclude that the largest part of the oak leaves mill is accumulated on the sieve with holes $0.25 \mathrm{~mm}$ in diameter $(30.9 \pm 2.9 \%)$, and a slightly lower fraction of mill is accumulated on the sieve with holes $0.63 \mathrm{~mm}$ in diameter $(28.1 \pm$ $3.2 \%$ ). The mill waste was high in dust, especially in oak bran with a dust content of $22.0 \pm 2.5 \%$. The largest fraction of mill mixture is accumulated on the sieve with holes $0.25 \mathrm{~mm}$ in diameter $(37.4 \pm$ $5.4 \%)$. The amount of dust was as high as $23.8 \pm 2.1 \%$.

When evaluating the quality of the milled oak waste, it can be stated that the oak waste was milled into very small fractions. It was found that the highest flour fraction was on the sieve with holes $0.25 \mathrm{~mm}$ in diameter (from $30.9 \pm 2.9 \%$ to $46.2 \pm 6.6 \%$ ), and the dust content was high (from 22.0 $\pm 2.5 \%$ to $24.3 \pm 2.3 \%$ ).

\subsection{Determination of Granules' Properties}

It has been determined that all the oak waste granules tested were suitable for incineration after a proper preparation. Using the investigated raw materials for energy conversion (burning), this oak waste (bark, leaves, and their mixture) was compressed into the form of granules with a diameter of $6 \mathrm{~mm}$. The main physical-mechanical properties-the moisture content and the density of the produced products - were then investigated (Table 3). 
Table 3. The moisture content and the density of the oak waste granules.

\begin{tabular}{ccc}
\hline Oak Waste Granules & Moisture Content, $\%$ & ${\text { Density, } \mathbf{~ k g ~}^{-3}}^{\mathbf{3}}$ \\
Bark & $8.1 \pm 0.1$ & $1221.1 \pm 64.4(1122.2 \mathrm{DM})$ \\
Leaves & $12.5 \pm 0.2$ & $1111.5 \pm 42.4(975.8 \mathrm{DM})$ \\
Bark and leaves mixture (1:1) & $10.6 \pm 0.1$ & $1131.2 \pm 91.0(1011.3 \mathrm{DM})$ \\
\hline
\end{tabular}

The moisture content of oak waste granules varied from $8.1 \pm 0.1 \%$ to $12.5 \pm 0.2 \%$. The estimated density of the oak bark granules was the biggest and reached $1122.2 \mathrm{~kg} \mathrm{~m}^{-3} \mathrm{DM}$ (dry mass). For comparison, the density of oak leaves granules was the lowest, with $975.8 \mathrm{~kg} \mathrm{~m}^{-3} \mathrm{DM}$.

The curves of the performed strength test of oak waste granules are presented in Figure 1. A mean characteristic curve was selected from 3 samples to show the nature of the force change in the strength test. Analysis of the deformation curves allowed us to observe that the highest crushing force (more than $450 \mathrm{~N}$ ) was achieved in the case of oak bark granules, and the strongest granules were the ones of the oak leaves (more than $730 \mathrm{~N}$ ) (Figure 2).

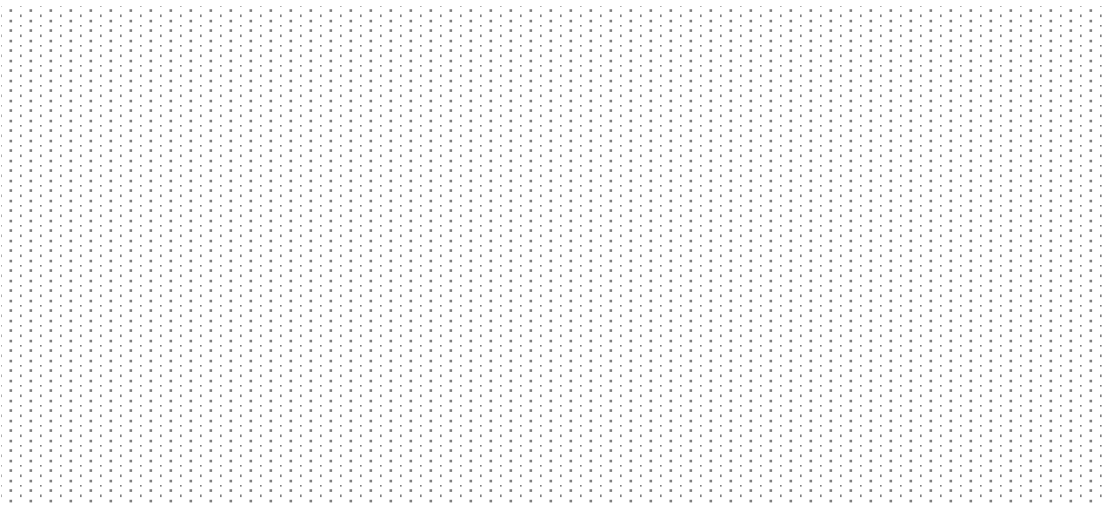

Figure 1. The strength test for the oak waste granules.

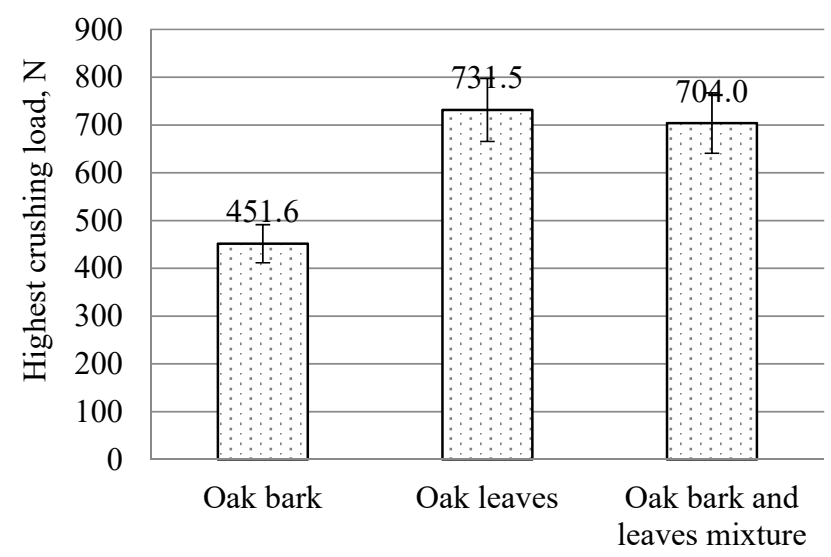

$(1: 1)$

Figure 2. The highest crushing load test for the oak waste granules.

\subsection{Evaluation of the Chemical and Thermal Properties of the Biofuel Granules}

Analysis of the chemical properties, ash content, and heating value of the oak waste products showed that the total carbon content was similar, ranging from $46.33 \pm 1.13 \%$ to $47.32 \pm 1.14 \%$; the hydrogen content ranged from $4.67 \pm 0.45 \%$ to $5.25 \pm 0.47 \%$, and the nitrogen and sulphur were low in volume (Table 4).

The ash amount of oak waste was very high and ranged from $10.34 \pm 0.22 \%$ to $14.66 \pm 0.60 \%$. It was about 9-10 times bigger than the ash amount of conventional biofuels [38,39]. The high amount of ash means that the burning quality of the oak waste granules was not sufficiently high. 
Table 4. Chemical properties, ash content, and caloric value of the oak waste granules.

\begin{tabular}{cccc}
\hline & \multicolumn{3}{c}{ Value, \% } \\
\cline { 2 - 4 } Granules' Parameters & Oak Bark & Oak Leaves & $\begin{array}{c}\text { Oak Bark and } \\
\text { Leaves Mixture 1:1 }\end{array}$ \\
\cline { 2 - 4 } & $46.33 \pm 1.13$ & $47.32 \pm 1.14$ & $47.18 \pm 1.23$ \\
Amount of carbon, \% & $5.23 \pm 0.43$ & $4.67 \pm 0.45$ & $5.25 \pm 0.47$ \\
Amount of hydrogen, \% & $0.88 \pm 0.31$ & $1.28 \pm 0.32$ & $1.06 \pm 0.31$ \\
Amount of nitrogen, \% & $0.08 \pm 0.27$ & $0.08 \pm 0.28$ & $0.09 \pm 0.27$ \\
Amount of sulphur, \% & 37.14 & 31.99 & 34.56 \\
Amount of oxygen, \% & $8.12 \pm 0.07$ & $12.52 \pm 0.07$ & $10.60 \pm 0.07$ \\
Amount of moisture, \% & $10.34 \pm 0.22$ & $14.66 \pm 0.60$ & $11.87 \pm 0.45$ \\
Amount of ash, \% & $17.42 \pm 0.69$ & $17.72 \pm 0.90$ & $17.26 \pm 1.13$ \\
Dry biofuel lower heating value, MJ kg ${ }^{-1}$ & $18.50 \pm 0.43$ & $18.68 \pm 0.69$ & $18.34 \pm 0.92$ \\
Dry biofuel high heating value, MJ kg ${ }^{-1}$ & $15.82 \pm 0.69$ & $13.81 \pm 0.93$ & $15.18 \pm 1.15$ \\
Wet biofuel lower heating value, MJ kg ${ }^{-1}$ & $17.00 \pm 0.43$ & $15.03 \pm 0.69$ & $16.40 \pm 0.92$ \\
Wet biofuel high heating value, MJ kg ${ }^{-1}$ & $1.00 \pm 0$
\end{tabular}

The lower heating value of the oak bark, leaves, and their mixture (1:1) granules was very similar and ranged from $17.26 \pm 1.13$ to $17.72 \pm 0.90 \mathrm{MJ} \mathrm{kg}^{-1} \mathrm{DM}$ (dry matter). The oak waste granules had a relatively high heating value, very similar to the heating value of the herbaceous plants and some other wood species, determined by the previous studies of the authors [34] and other researchers [40].

\subsection{The Results of Harmful Emissions from the Combustion of Oak Waste Granules}

While burning the oak waste granules, the smoke temperature was recorded and the harmful emissions, such as carbon dioxide, carbon monoxide, sulphur dioxide, nitrogen oxides. and unburnt hydrocarbons, were determined. These research results are presented in Figures 3-5.

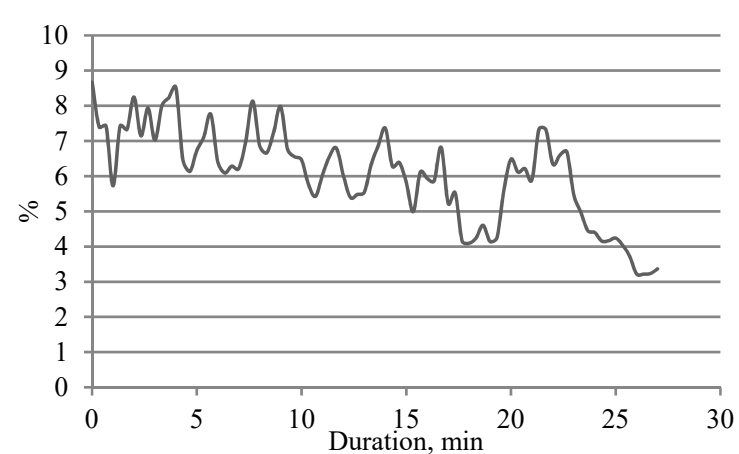

(a)

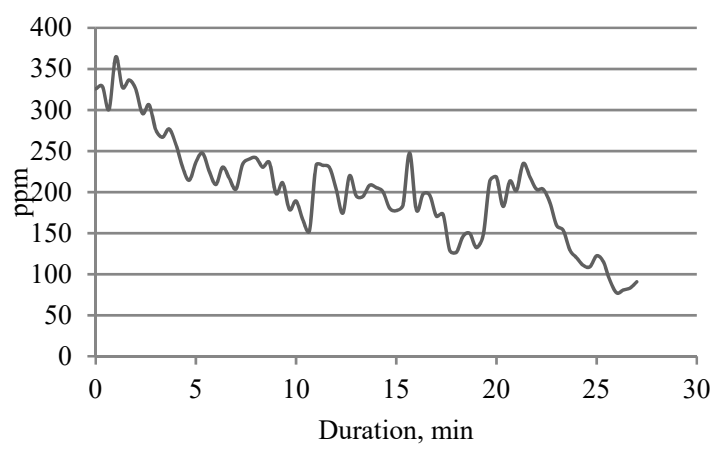

(c)

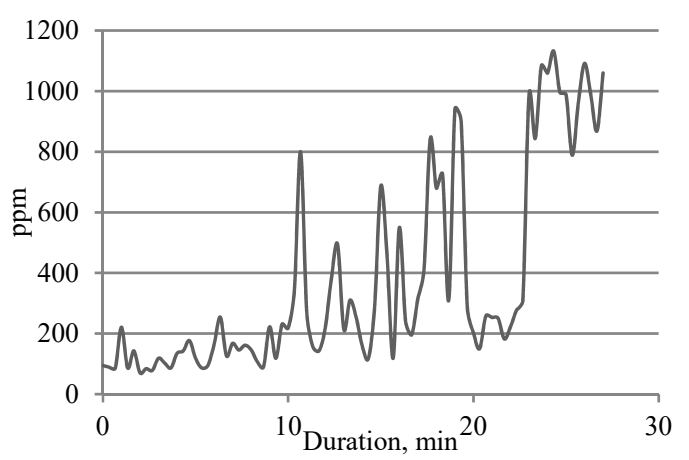

(b)

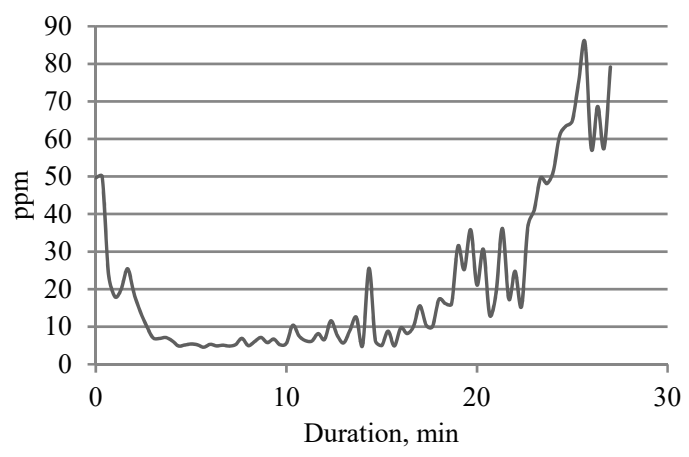

(d)

Figure 3. Harmful emissions from the combustion of oak bark granules: (a) carbon dioxide $\left(\mathrm{CO}_{2}\right)$, (b) carbon monoxide $(\mathrm{CO})$, (c) nitrogen oxides $\left(\mathrm{NO}_{\mathrm{x}}\right)$, (d) hydrocarbons $\left(\mathrm{C}_{\mathrm{x}} \mathrm{H}_{\mathrm{y}}\right)$. 


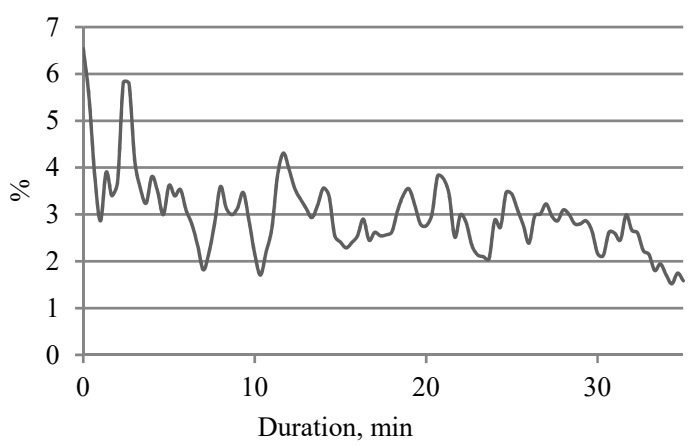

(a)

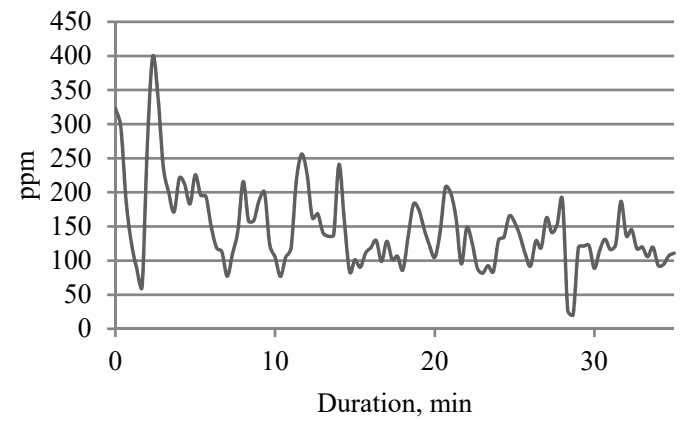

(c)

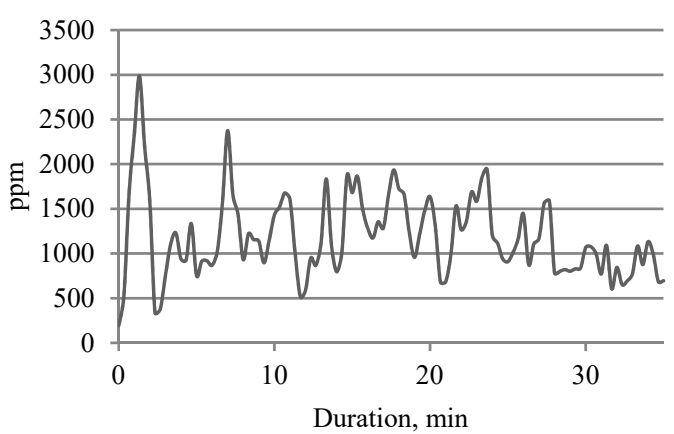

(b)

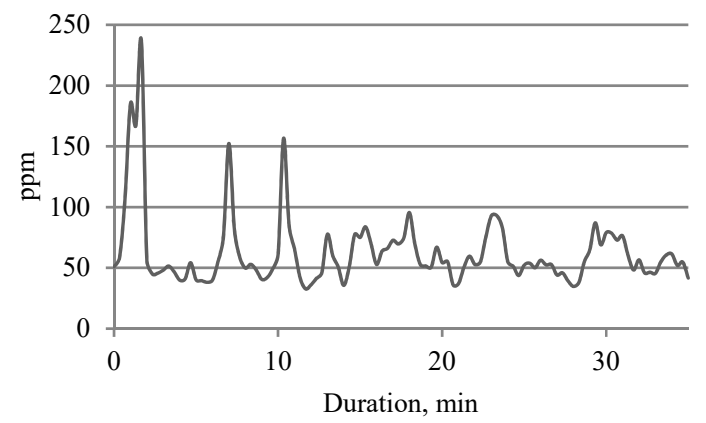

(d)

Figure 4. Harmful emissions from the combustion of oak leaf granules: (a) carbon dioxide $\left(\mathrm{CO}_{2}\right)$, (b) carbon monoxide (CO), (c) nitrogen oxides (NOx), (d) hydrocarbons $\left(\mathrm{C}_{\mathrm{x}} \mathrm{H}_{\mathrm{y}}\right)$.

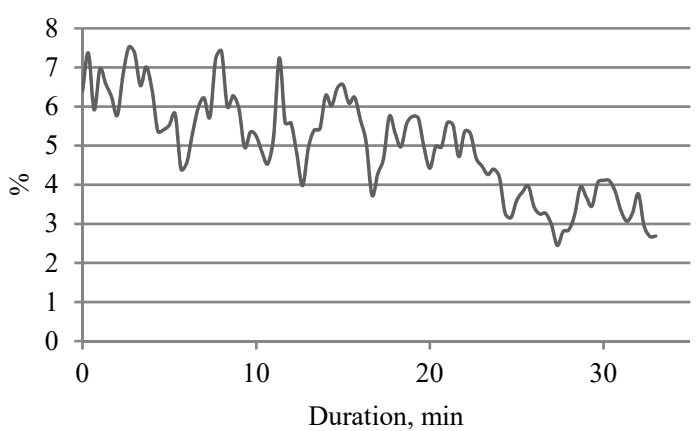

(a)

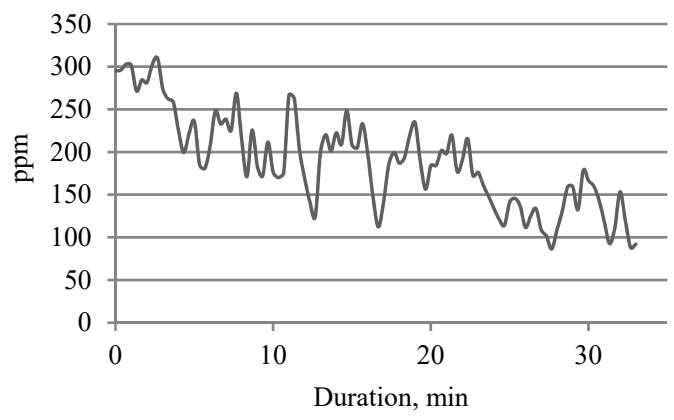

(c)

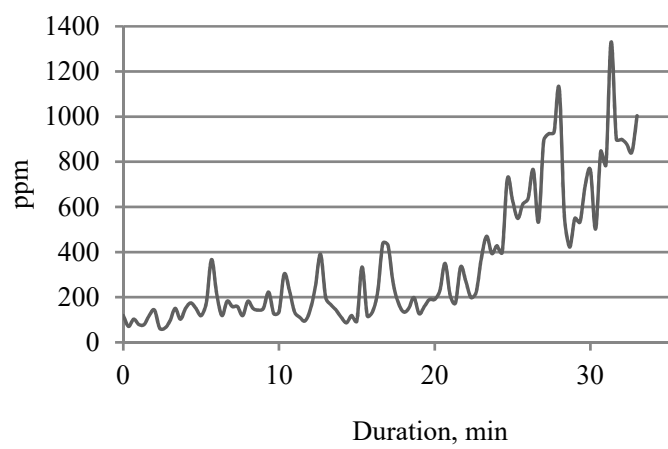

(b)

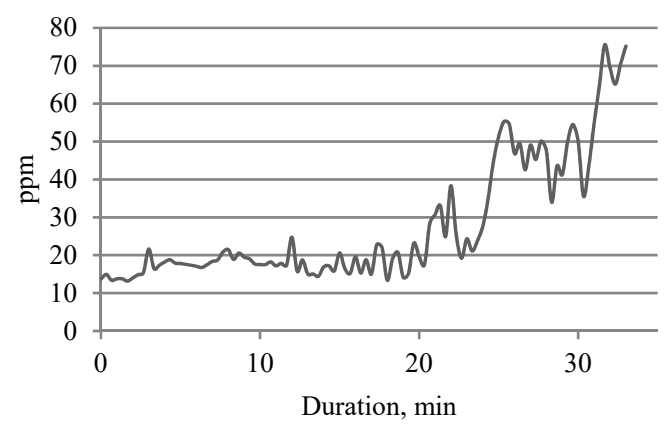

(d)

Figure 5. Harmful emissions from the combustion of the oak leaf and bark mixture (1:1) granules: (a) carbon dioxide $\left(\mathrm{CO}_{2}\right),(\mathbf{b})$ carbon monoxide $(\mathrm{CO})$, (c) nitrogen oxides $\left(\mathrm{NO}_{\mathrm{x}}\right)$, (d) hydrocarbons $\left(\mathrm{C}_{\mathrm{x}} \mathrm{H}_{\mathrm{y}}\right)$.

According to the research results, a general trend is visible in the burning process: all the harmful combustion gases tend to decrease when the burning becomes of low intensity. 
The results show that the highest concentration of carbon monoxide (CO) was determined when burning oak leaves-it reached $1187.7 \mathrm{mg} \mathrm{m}^{-3}$. The lowest concentration of $\mathrm{CO}$ was recorded when burning the oak bark and leaf mixture granules, and it was $341.2 \mathrm{mg} \mathrm{m}^{-3}$ (Table 5). The sulphur dioxide $\left(\mathrm{SO}_{2}\right)$ emissions were not recorded while burning the oak waste.

Table 5. Test results of the harmful emissions when burning the oak waste granules.

\begin{tabular}{cccccc}
\hline Type of Biofuel & $\begin{array}{c}\text { Smoke } \\
\text { Temperature, } \\
{ }^{\circ} \mathbf{C}\end{array}$ & $\begin{array}{c}\mathbf{C O}_{\mathbf{2}} \\
\mathbf{m g ~ m}^{-3}\end{array}$ & $\begin{array}{c}\mathbf{C O} \\
\mathbf{m g ~ m}^{-3}\end{array}$ & $\begin{array}{c}\mathbf{N O}_{\mathbf{x}} \\
\mathbf{m g ~ m}^{-3}\end{array}$ & $\begin{array}{c}\mathbf{C}_{\mathbf{x}} \mathbf{H}_{\mathbf{y}} \\
\mathbf{m g ~ m}^{-3}\end{array}$ \\
\hline Oak bark granules & 197.9 & 6.1 & 377.4 & 202.9 & 21.1 \\
$\begin{array}{c}\text { Oak leaves granules } \\
\text { Oak bark and leaves } \\
\text { mixture granules }\end{array}$ & 187.1 & 3.0 & 1187.7 & 146.5 & 62.8 \\
\hline
\end{tabular}

During the burning of oak waste granules, high carbon dioxide $\left(\mathrm{CO}_{2}\right)$ emissions were recorded. The highest content of carbon dioxide $6.1 \mathrm{mg} \mathrm{m}^{-3}$ was determined by burning the oak bark granules and the lowest $\mathrm{CO}_{2}$ content $\left(3.0 \mathrm{mg} \mathrm{m}^{-3}\right)$ by burning the oak leaf granules.

The results of the combustion of the granules and the evaluation of the $\mathrm{NO}_{\mathrm{x}}$ emissions show that the emissions did not exceed permissible levels. The nitrogen oxide emissions ranged from 146.5 (oak leaf granules) to $202.9 \mathrm{mg} \mathrm{m}^{-3}$ (oak bark granules).

The results of the research in Finland and Poland showed that the CO concentration of wood granules was $1.3 \pm 1.9 \mathrm{~g} / \mathrm{kg}$, and the $\mathrm{CO}$ concentration of straw pellets was $4-5$ times higher, at 6.4 $\pm 5.0 \mathrm{~g} / \mathrm{kg}$. The $\mathrm{NO}_{x}$ concentration, meanwhile, was $3.6 \pm 0.8$ and $1.4 \pm 0.2 \mathrm{~g} / \mathrm{kg}$, respectively. Other researchers estimated that the concentration of CO after burning the peat granules was $140 \pm 297 \mathrm{mg} / \mathrm{MJ}$, and the concentration of $\mathrm{NO}_{x}$ was $225 \pm 29 \mathrm{mg} / \mathrm{MJ}[41,42]$.

The quantities of unburnt hydrocarbons $\mathrm{C}_{\mathrm{x}} \mathrm{H}_{\mathrm{y}}$ after burning the oak waste granules were sufficiently low (21.1 to $62.8 \mathrm{mg} \mathrm{m}^{-3}$ ) (Table 5). Polish scientists evaluated the concentration of hydrocarbons in wood granules and detected low values of unburnt hydrocarbons as well (24.0-61.0 ppm) [38].

\subsection{Energy Assessment of Oak Waste Biofuel Preparation and Use for Burning Technology}

When evaluating technology for the biofuel preparation of milled and recycled (granulated) oak waste, it is important to justify and propose the technology and technological operations and select the technique.

The calculation of the direct energy consumption (fuel and electricity) for the preparation of granulated biofuel from oak leaves is presented in Table 6.

Table 6. The direct energy consumption for the preparation of granulated biofuel from oak leaves. (yield of leaves $4 \mathrm{tha}^{-1}$, moisture content $25 \%$ ).

\begin{tabular}{|c|c|c|}
\hline \multirow{2}{*}{ Technological Operations } & \multicolumn{2}{|c|}{ Energy Consumption } \\
\hline & MJ ha $\mathbf{h}^{-1}$ & MJ kg $\mathbf{k g}^{-1}$ \\
\hline Energy consumption for granule production & & \\
\hline Energy consumption for the collection of leaves into piles & 4000 & 1.0 \\
\hline Loading of oak leaves into vehicle trailers and transportation & 4400 & 1.1 \\
\hline $\begin{array}{c}\text { Milling and drying of biomass in a dryer-dispergator, reducing } \\
\text { the moisture content from } 25 \% \text { to } 15 \%\end{array}$ & 8400 & 2.1 \\
\hline $\begin{array}{c}\text { Granule production (diameter of } 6 \mathrm{~mm}) \text { in a low-power }(7.5 \mathrm{~kW}) \\
\text { granulator }\end{array}$ & 1900 & 0.12 \\
\hline Energy consumption of granule transportation and burning implements & 1100 & 0.07 \\
\hline Total: & 19,800 & 4.37 \\
\hline
\end{tabular}


It was determined that the energy consumption for the total pressed biofuel preparation of oak leaves, when the biomass moisture content was reduced from $25 \%$ to $15 \%$, was $4.37 \mathrm{MJ} \mathrm{kg} \mathrm{kg}^{-1}$. Taking into account that the determined lower calorific value of the oak leaf dry matter is sufficiently high - $17.7 \mathrm{MJ} \mathrm{kg}^{-1} \mathrm{DM}$ - and the efficiency of the boiler is 0.9 , the coefficient of energy efficiency $R$ of the granulated oak leaf biofuel when the oak waste biomass moisture content is reduced by $10 \%$ will be equal to $3.64(R=17.7 \times 0.9: 4.37=3.64)$.

The comparison of these research results with our previous research studies of pressed straw biofuel [14] allows us to state that the results were very similar due to the fact that the energy efficiency coefficient $R$ of the granulated various types of straw biofuel reached 3.5-3.7. Farmers sometimes use special boilers for burning baled straw, but when the burning of baled straw is used directly for heat energy production, the coefficient of energy efficiency $R$ can reach even 5.6-6.0. As we can see, the straw energy efficiency is about 1.6 times higher; however, it is expedient to use oak waste for biofuels, as these are the residues that we need to remove from oak forests or parks. Oak leaves have high lower calorific value, which can reach $17.7 \mathrm{MJ} \mathrm{kg}^{-1} \mathrm{DM}$; oak waste biofuel can be used as an environmentally friendly biofuel, minimally polluting the surrounding atmosphere when burnt.

In summary, the results of testing the oak waste burning and emissions showed that oak bark, leaves, and their mixtures can be recommended for use in solid biofuels after being granulated. However, this may require additional energy consumption for mass drying. Such combustion of biofuels produces enough high-quality and efficient combustion and low emissions into the environment. Very similar research results were obtained after the investigation of the properties and environmental impacts of different energy plants and their waste in Lithuania and other European countries.

After assessing the sustainability aspects of the use of the investigated oak waste for energy purposes, it can be stated that the most extensive analysis of the environmental impact of burning granulated oak waste biofuel has been carried out in the conducted research. The ash from the incineration of the pellets can be used to fertilize plants, thus not polluting the environment.

The economic impact of the preparation and the use of oak waste for biofuels has not been calculated, but the economic benefits of such biofuels can be justified by evaluating oak leaves and bark as waste, which does not cost extra.

In addition to the positive features mentioned above, the combustion of granulated biofuels provides significant social benefits. Such biofuels are suitable for boilers with fully automated pellet supply and combustion. A pellet boiler not only provides warmth of the desired comfort in the house, but also heats the house reliably and safely for 10 or more years. The latest pellet boilers are modern and fully automated and do not need to be manually ignited. All boiler operation settings can be controlled via mobile devices—smartphone, computer, or a tablet—by connecting to the boiler online.

\section{Conclusions}

After evaluating the quality of the oak waste mill, it can be noted that the prepared oak waste mill had too-small fractions. The sieve with holes $0.25 \mathrm{~mm}$ in diameter (from $30.9 \pm 2.9 \%$ to $46.2 \pm 6.6 \%$ ) produced the biggest mill fraction and an excessively high dust content (from $22.0 \pm 2.5 \%$ to $24.3 \pm$ $2.3 \%)$.

The moisture content of the oak waste granules ranged from $8.1 \%$ to $12.5 \%$. After the investigation of the density of the prepared oak waste granules, it was found that the density of the oak bark granules was the highest, with $1122.2 \mathrm{~kg} \mathrm{~m}^{-3} \mathrm{DM}$, and the density of oak leaves granules was the smallest (975.8 $\left.\mathrm{kg} \mathrm{m}^{-3} \mathrm{DM}\right)$.

The evaluation of the elemental composition of the oak biofuel granules indicated that the amount of carbon was similar and ranged from $46.3 \%$ to $47.3 \%$, and the amount of hydrogen ranged from $4.7 \%$ to $5.3 \%$. It should be noted that the amount of other chemical elements, such as sulphur and nitrogen, was relatively low.

It has been determined that the amount of ash was 9-10 times higher compared with conventional biofuels and ranged from $10.4 \%$ to $14.7 \%$. The lower calorific value for burning the oak bark, leaves, 
and their granules ranged from 17.3 to $17.7 \mathrm{MJ} \mathrm{kg}^{-1} \mathrm{DM}$. The oak waste granules had a relatively high calorific value, close to the calorific value of the herbaceous plants and some wood species.

It was established that the oak waste granules emit harmful pollutants-carbon monoxide $\mathrm{CO}$, sulphur dioxide $\mathrm{SO}_{2}$, carbon dioxide $\mathrm{CO}_{2}$. and nitrogen oxides $\mathrm{NO}_{x}$-when burning. The highest concentration of CO was found when burning the oak leaves $\left(1187.70 \mathrm{mg} \mathrm{m}^{-3}\right)$, and the lowest $\mathrm{NO}_{\mathrm{x}}$ concentration was found when burning the mixture of oak bark and leaves-341.2 $\mathrm{mg} \mathrm{m}^{-3}$. The emissions of other harmful gas did not exceed the permissible limits.

The coefficient of the energy efficiency $R$ of the oak leaf granules, determined when the oak waste biomass moisture content was reduced by $10 \%$, was equal to 3.64. For comparison, previous research studies on granulated straw biofuel obtained very similar results-the coefficient $R$ of granulated various types of straw biofuel varied from 3.5 to 3.7 .

The results of the research of complex oak waste granule preparation and the investigation of its burning and emissions showed that the waste and its mixtures should be recommended for burning in domestic boilers. In addition, such biofuel is convenient to use in the fully automated process of pressed biomass feeding and burning.

Author Contributions: Conceptualization, A.J. and R.M.; methodology, A.J.; investigation, A.J., R.M., and E.J.; resources, R.D. and E.V.; data curation, A.J. and R.M.; writing-original draft preparation, A.J. and R.M.; writing-review and editing, E.J. and M.M.; supervision, A.J. and E.J.; funding acquisition, R.D. and E.V. All authors have read and agreed to the published version of the manuscript.

Funding: This research received no external funding.

Conflicts of Interest: The authors declare no conflict of interest.

\section{References}

1. Filbakk, T.; Jirjis, R.; Nurmi, J.; Hoibo, O. The effect of bark content on quality parameters of Scots pine (Pinus sylvestris L.) pellets. Biomass Bioenergy 2011, 35, 3342-3349. [CrossRef]

2. Verma, V.K.; Bram, S.; Delattin, F.; Laha, P.; Vandendael, I.; Hubin, A.; De Ruyck, J. Agro-pellets for domestic heating boilers: Standard laboratory and real life performance. Appl. Energy 2012, 90, 17-23. [CrossRef]

3. Hartmann, H.; Lenz, V. Biomass energy heat provision in modern small-scale systems. In Encyclopedia of Sustainability Science and Technology; Springer: New York, NY, USA, 2012; pp. 1351-1400.

4. Thek, G.; Obernberger, I. The pellet handbook: The production and thermal utilization of biomass pellets. Routledge, 2012. Available online: https://www.taylorfrancis.com/books/9781136539923 (accessed on 21 May 2020).

5. Johansson, L.S.; Leckner, B.; Gustavsson, L.; Cooper, D.; Tullin, C.; Potter, A. Emission characteristics of modern and old-type residential boilers fired with wood logs and wood pellets. Atmospheric Environ. 2004, 38, 4183-4195. [CrossRef]

6. Ståhl, M.; Wikström, F. Swedish perspective on wood fuel pellets for household heating: A modified standard for pellets could reduce end-user problems. Biomass Bioenergy 2009, 33, 803-809. [CrossRef]

7. Samuelsson, R.; Thyrel, M.; Sjöström, M.; Lestander, T.A. Effect of biomaterials characteristics on pelletizing properties and biofuel pellet quality. Fuel Process. Technol. 2009, 90, 1129-1134. [CrossRef]

8. Kirsanovs, V.; Timma, L.; Zandeckis, A.; Romagnoli, F. The quality of pellets available on the market in Latvia: Classification according EN 14961 requirements. Sci. J. Riga Tech. Univ. Environ. Clim. Technol. 2012, 8, 36-40. [CrossRef]

9. Dias, J.; Costa, M.; Azevedo, J.L.T. Test of a small domestic boiler using different pellets. Biomass Bioenergy 2004, 27, 531-539. [CrossRef]

10. Rabaçal, M.; Fernandes, U.; Costa, M. Combustion and emission characteristics of a domestic boiler fired with pellets of pine, industrial wood waste and peach stones. Renew. Energ. 2013, 51, 220-226. [CrossRef]

11. Sultana, A.; Kumar, A. Ranking of biomass pellets by integration of economic, environmental and technical factors. Biomass Bioenergy 2012, 39, 344-355. [CrossRef]

12. Raslavičius, L.; Kučinskas, V.; Jasinskas, A. The prospects for energy forestry and agro-residues in the Lithuania's domestic energy supply. Renew. Sust. Energ. Rev. 2013, 22, 419-431. [CrossRef] 
13. Jasinskas, A.; Šiaudinis, G.; Martinkus, M.; Karčiauskienė, D.; Repšienè, R.; Pedišius, N.; Vonžodas, T. Evaluation of Common Osier (Salix viminalis L.) and Black Poplar (Populus nigra L.) biomass productivity and determination of chemical and energetic properties of chopped plants produced for biofuel. Balt. For. 2017, 23, 666-672.

14. Jasinskas, A.; Sakalauskas, A.; Šarauskis, E.; Vaiciukevičius, E.; Kalinauskaitè, S. Investigation of boiler efficiency and harmful emissions while burning of plant biomass briquettes. J. Food Agric. Environ. 2012, 10, 1124-1127.

15. Sari, R.; Soytas, U. Are global warming and economic growth compatible? Evidence from five OPEC countries. Appl. Energy 2009, 86, 1887-1893. [CrossRef]

16. LAND 43-2013. Emission Rates for Combustion Plants. 2013. [In Lithuanian]. Available online: https://www.aplinkosvadyba.lt/index.php/naujienos/77-patvirtinti-nauji-ir-pakeisti-esaminormatyviniai-dokumentai-reglamentuojantys-tersalu-ismetima-is-kura-deginanciu-irenginiu. (accessed on 21 May 2020).

17. Vares, V.; Kask, U.; Muiste, P.; Pihu, T.; Soosaar, S. Biofuel User Manual; Žara publisher: Vilnius, Lithuania, 2007; p. 168. (In Lithuanian)

18. Verhoest, C.; Ryckmans, Y. Industrial Wood Pellets Report. Laborelec, PellCert, Intelegent Energy Europe. 2012. Available online: http://www.bpa-intl.com/images/stories/present-1/PELLCERT\%20-\%20Industrial\% 20Wood\%20Pellets\%20Report\%20(2012).pdf (accessed on 29 June 2020).

19. Bioenergy Europe's Statistical Report. 2018. Available online: https://bioenergyeurope.org/statistical-report (accessed on 21 May 2020).

20. Adapa, P.K.; Tabil, L.G.; Schoenau, G.J.; Crerar, B.; Sokjansanj, S. Peletization of alfalfa grinds-compression characteristics of fractionated alfalfa grinds. Powder Handl. Process. 2002, 14, 252-259.

21. Larsson, S.H.; Thyrel, M.; Geladi, P.; Lestander, T.A. High quality biofuel pellets production from pre-compacted low density raw materials. Bioresour. Technol. 2008, 99, 7176-7182. [CrossRef]

22. Simpson, W.; TenWolde, A. Physical properties and moisture relations of wood. Chapter 1999, 3, 2-1.

23. Robbins, W.C. Density of wood chips. J. For. 1982, 80, 567-576.

24. Deutsches Institut Fur Normung (DIN). Testing of Solid Fuels. Compressed Untreated Wood. Requirements and Testing; German National Standard: Berlin, Germany, 1996.

25. Sokhansanj, S.; Turhollow, A.F. Biomass densification-cubing operations and costs for corn stover. Appl. Eng. Agric. 2004, 20, 495-500. [CrossRef]

26. Kaliyan, N.; Morey, R.V. Factors affecting strength and durability of densified biomass products. Biomass Bioenergy 2009, 33, 337-359. [CrossRef]

27. Gilbert, P.; Ryu, C.; Sharifi, V.; Swithenbank, J. Effect of process parameters on palletisation of herbaceous crops. Fuel 2009, 88, 1491-1497. [CrossRef]

28. Junginger, M.; Faaij, A.; Van den Broek, R.; Koopmans, A.; Hulscher, W. Fuel supply strategies for large-scale bio-energy projects in developing countries. Electricity generation from agricultural and forest residues in Northeastern Thailand. Biomass Bioenergy 2001, 21, 259-275. [CrossRef]

29. Magelli, F.; Boucher, K.; Bi, H.T.; Melin, S.; Bonoli, A. An environmental impact assessment of wood pellets exported from Canada to Europe. Biomass Bioenergy 2009, 33, 434-441. [CrossRef]

30. Rhén, C.; Öhman, M.; Gref, R.; Wästerlund, I. Effect of raw materials composition in woody biomass pellets on combustion characteristics. Biomass Bioenergy 2007, 31, 66-72. [CrossRef]

31. Li, H.; Liu, X.; Legros, R.; Bi, X.T.; Lim, C.J.; Sokhansanj, S. Pelletization of torrefied sawdust and properties of torrefied pellets. Appl. Energy 2012, 93, 680-685. [CrossRef]

32. Lam, P.S.; Sokhansanj, S.; Bi, X.; Lim, C.J.; Melin, S. Energy input and quality of pellets made of steam-exploded Douglas fir (Pseudotsuga menziesii). Energy Fuel 2011, 25, 1521-1528. [CrossRef]

33. Sjostrom, E. Wood Chemistry: Fundamentals and Applications; Gulf Professional Publishing: Houston, TX, USA, 1993.

34. Šiaudinis, G.; Jasinskas, A.; Šarauskis, E.; Steponavičius, D.; Karčiauskienè, D.; Liaudanskienė, I. The assessment of Virginia mallow (Sida hermaphrodita Rusby) and cup plant (Silphium perfoliatum L.) productivity, physico-mechanical properties and energy expenses. Energy 2015, 93, 606-612.

35. ES DD CEN/TS 15149-1: 2006. Solid Biofuels-Methods for the Determination of Particle Size Distribution-Part 1: Oscillating Screen Method Using Sieve Apertures of $3.15 \mathrm{~mm}$ and Above. Available online: https: //www.iso.org/standard/60685.html (accessed on 29 June 2020). 
36. CEN/TC 14774-1: 2005. Solid biofuels-Methods for the Determination of Moisture Content. Oven Dry Method-Part 1. Total Moisture-Reference Method. Available online: https: //www.google.com.hk/url?sa=t\&rct=j\&q=\&esrc=s\&source=web\&cd=\&ved=2ahUKEwiKt5zgtY3sAhWD_ KQKHQgPBkcQFjAAegQIBhAB\&url=https\%3A\%2F\%2Fwww.techstreet.com\%2Fans\%2Fproducts\% 2Fpreview\%2F1902937\&usg=AOvVaw2dnrlutlqCZE4WUCAPWw8i (accessed on 29 June 2020).

37. Jasinskas, A.; Sakalauskas, A.; Domeika, R. Evaluation of physical-mechanical properties of herbaceous bioenergy plants. Biomass Bioenergy 2008, 32, 952-958. [CrossRef]

38. Stolarski, M.J.; Krzyzaniak, M.; Warminski, K.; Tworkowski, J.; Szczukowski, S. Willow biomass energy generation efficiency and greenhouse gas reduction potential. Pol. J. Environ. Stud. 2015, 24, 2627-2640. [CrossRef]

39. Carvalho Rochaa, J.U.; Campolina Machadob, J.; Souza Carneiroa, P.C.; Costa Carneirob, J.; Vilela Resendec, M.D.; Vander Pereirab, A.; Souza Carneiroa, J.E. Elephant grass ecotypes for bioenergy production via direct combustion of biomass. Ind. Crop. Prod. 2017, 95, 27-36. [CrossRef]

40. Sippula, O.; Lamberg, H.; Leskinen, J.; Tissari, J.; Jokiniemi, J. Emission and ash behaviour in a $500 \mathrm{~kW}$ pellet boiler operated with various blends of woody biomass and peat. Fuel 2017, 202, 144-153. [CrossRef]

41. Kortelainen, M.; Jokiniemi, J.; Nuutinen, I.; Torvela, T.; Lamberg, H.; Karhunen, T.; Tissari, J.; Sippula, O. Ash behaviour and emission formation in a small-scale reciprocatinggrate combustion reactor operated with wood chips, reed canary grass and barley straw. Fuel 2015, 143, 80-88. [CrossRef]

42. Szyslak-Barglowicz, J.; Zajac, G.; Slowik, T. Hydrocarbon emissions during biomass combustion. Pol. J. Environ. Stud. 2015, 24, 1349-1354. [CrossRef]

(C) 2020 by the authors. Licensee MDPI, Basel, Switzerland. This article is an open access article distributed under the terms and conditions of the Creative Commons Attribution (CC BY) license (http://creativecommons.org/licenses/by/4.0/). 